\title{
Ethnofederalism in Ethiopia: An Analysis on the Implementation and Impact of Ethnofederalism in Domestic Ethnic Conflict within the State of Ethiopia
}

\author{
Erin McGeachie
}

Attempts are currently being made to resolve the problem that a colonial history has created within multi-ethnic states, by granting autonomy to groups whose culture and identity has been suppressed in the unity of modern nation-state ${ }^{1}$. The system of ethnofederalism was created to allow conflicting ethnic communities to obtain a level of autonomy and self-government from the central authority without resorting to secession ${ }^{2}$. Specifically ethnofederalism allows for regional political communities to provide a nonviolent means of dealing with differences between these groups ${ }^{3}$. This paper will argue for the effectiveness of ethnofederalism when a state's constitutional structure supports the equilibrium of power between central and state autonomy. This will be argued in terms of the necessity for a successful division of fiscal power, equity between the ethnic groups, federal toleration for political dissent and the implementation of fail-safes to prevent federal domination over regional governance.

To support my thesis I will look at the case of Ethiopia and dissect the reasons for the unsuccessful execution of ethnofederalism within this conflicting multi-ethnic state. I

\footnotetext{
${ }^{1}$ Herther-Spiro, Nicole B. 2007. “Can Ethnic Federalism Prevent 'Recourse to Rebellion?': A Comparative Analysis of the Ethiopian and Iraqi Constitutional Structures.” Emory International Law Review 21:322.

2 Clapham, Christopher. 2009. "Post-war Ethiopia: The Trajectories of Crisis." Review of African Political Economy 36:183.

${ }^{3}$ Herther-Spiro, Nicole B. 2007. 'Can Ethnic Federalism Prevent 'Recourse to Rebellion?': A Comparative Analysis of the Ethiopian and Iraqi Constitutional Structures.” Emory International Law Review 21:322.
}

ERIN MCGEACHIE is currently a second year student at Queen's University in Kingston, Ontario. She was born and raised in Oshawa, Ontario. Erin is pursuing a Bachelor of Arts degree with a Major in Political Studies and a concentration in International Relations. She in engaged with the Queen's Model United Nations, the Queen's Model Parliament and is on the Social Issues Commission for Religious Issues on campus. Erin plans to pursue a graduate degree in Policy Studies. 
will begin with the history of ethnofederalism in Ethiopia. Following this I will analyze this constitutional structure and analyze the reasons for its failure, namely an unsuccessful division of fiscal power, a lack of equity between ethnic factions, little federal toleration for political dissent and a federal domination over regional governance. This paper will suggest changes to be implemented in Ethiopia according to the theoretical framework of ethnofederalism, as an effective means of reducing state conflict. Finally I will discuss the implications of Ethiopia's failed attempt to execute federalism as positive for the development of the theory of ethnofederalism.

There has been a persistent history of authoritarian rule and suppression within Ethiopia, beginning with Emperor Menelik II from 1889-1913. Menelik's imperialist attitude led to his empire's territorial and demographic expansion southwards ${ }^{4}$. This led to the inclusion of various ethnic and national groups under the Christian northern Ethiopian empire, who were discriminated against as non-Christians and for their language differences ${ }^{5}$. This discrimination persisted with Emperor Haile Selassie who ruled prior to the 1974 coup, where his coercive assimilation tactics involved heavily restricting language and religion rights of the non-Amara majority ${ }^{6}$.

Following the 1974 coup the Derg, an authoritarian socialist regime, came to power and began the Red Terror campaign which silenced political opposition towards the government ${ }^{7}$. After the Derg government fell in 1991, leaving rebel groups in control of the country, the Tigrayan Peoples Liberation Front (TPLF) formed to create a transitional government. After the 1992 election, a Constitutional Commission was formed which established the Federal Democratic Republic of Ethiopia ${ }^{8}$. Under this constitution a two-tiered ethnofederal system was instituted which would create partially autonomous states whose borders were to be drawn along ethno-linguistic lines ${ }^{9}$.

\footnotetext{
${ }^{4}$ Ibid., 334.

${ }^{5}$ Ibid., 334.

${ }^{6}$ Ibid., 344.

${ }^{7}$ Ibid., 344.

${ }^{8}$ Adegehe, Asnake K. 2009. Federalism and ethnic conflict in Ethiopia: a comparative study of the Somali and Benishangul-Gumuz regions. Leiden: Leiden University Press: 14.

${ }^{9}$ Herther-Spiro, Nicole B. 2007. "Can Ethnic Federalism Prevent 'Recourse to Rebellion?': A Comparative Analysis of the Ethiopian and Iraqi Constitutional Structures." Emory International Law Review 21:336
} 
The transitional government formed a coalition with several other popular political parties under Meles Zenawi ${ }^{10}$. He founded the Ethiopian People's Revolutionary Democratic Front (EPRDF) which declared its intent to establish a new social order based on equality, rule of law and self-determination ${ }^{11}$. The EPRDF claimed that Ethiopia's problems were derived from a history of economic exploitation which could be remedied $^{12}$. This would be achievable by nationalizing land and vesting its control in peasants associations ${ }^{13}$. Through this Ethiopia would become free from exploitation and could thus build a united state under a socialist and nationalist government ${ }^{14}$.

Ethiopia is generally considered a prime example of the success of ethnofederalism internationally and an illustration of "good governance"15. However, the persisting ethnic conflicts and mismanagement by the state exemplify the failure of ethnofederalism to be effectively implemented. Ethnofederalism is only a successful system towards the goal of ending ethnic conflict if it is administrated properly through a successful balance of power between state and central authority. The theory of ethnofederalism surrounds the idea that the local governments would harmonize intergroup conflicts through non-violent expressions of opinion, which would not otherwise have been accessible ${ }^{16}$. Ethnofederalism is executed through the territorial sub-division of a state along ethno-linguistic borders in an attempt to divide political power according to each distinct ethnic faction ${ }^{17}$.

According to the theory of ethnofederalism, the effect of a territorial division would be a reduction in ethnic conflict because it provides ethnic groups the official recognition they seek without dissolving the state ${ }^{18}$. Furthermore the recognition of

\footnotetext{
${ }^{10}$ Clapham, Christopher. 2009. "Post-war Ethiopia: The Trajectories of Crisis." Review of African Political Economy 36:182.

${ }^{11}$ Ibid., 182.

12 Ibid., 183.

${ }^{13}$ Ibid., 183.

${ }^{14}$ Ibid., 183.

${ }^{15}$ Ibid., 183.

${ }^{16}$ Herther-Spiro, Nicole B. 2007. “Can Ethnic Federalism Prevent 'Recourse to Rebellion?': A

Comparative Analysis of the Ethiopian and Iraqi Constitutional Structures." Emory International Law

Review 21:330.

${ }^{17}$ Ibid., 323.

${ }^{18}$ Ibid., 322.
} 
differences would assist in mitigating past conflicts ${ }^{19}$. The main goal is the attempt to account for the contested nature of ethnic identity in contemporary Ethiopian politics, such as through minority rights, referendums and ethnic-based political parties, to determine ethnic identity ${ }^{20}$. This may not necessarily involve eliminating conflicts, because conflict has many positive benefits for a state, including progression. Rather the solution would be creating a system which allows for citizens to express their opinions and differences in a non-violent manner $^{21}$. This would allow for cooperation among political elites and enhance government accountability as a tool of reducing ethnic conflict $^{22}$. Thus by creating a system which acknowledged differences, rather than trying to ignore or assimilate them, resolutions that are acceptable for the majority of the population can be reached and greater autonomy will be accessible for minority ethnic groups. Thus Ethiopia seeks a new national interest of its citizens' rights, freedoms and justice, rather than that of the dictatorship that controls the state.

The Constitution of 1994 declared a new ethnofederal system to be in place in Ethiopia, where a two-tiered federal system would ensure representation of minorities through state borders being drawn on ethno-linguistic lines ${ }^{23}$. Notably ethnic groups separated through state borders were the Amara, Tigrayan, Oromo and Eritrean factions who represent large portions of the population. The central government was declared a Parliamentary system with a House of Peoples Representatives and a House of Federation. Within the House of Peoples Representatives, individuals are elected in direct elections for a term of 5 years; in addition provisions are made for minority nationalities $^{24}$. In the House of Federation each nation, nationality, and peoples are given

\footnotetext{
${ }^{19}$ Ibid., 322.

${ }^{20}$ Smith, Lahra. 2007. "Voting for an ethnic identity: procedural and institutional responses to ethnic conflict in Ethiopia." Journal of modern African studies 45:565.

${ }^{21}$ Herther-Spiro, Nicole B. 2007. 'Can Ethnic Federalism Prevent 'Recourse to Rebellion?': A

Comparative Analysis of the Ethiopian and Iraqi Constitutional Structures.” Emory International Law Review 21:332.

${ }^{22}$ Smith, Lahra. 2007. "Voting for an ethnic identity: procedural and institutional responses to ethnic conflict in Ethiopia." Journal of modern African studies 45:567.

${ }^{23}$ Herther-Spiro, Nicole B. 2007. “Can Ethnic Federalism Prevent 'Recourse to Rebellion?': A Comparative Analysis of the Ethiopian and Iraqi Constitutional Structures.” Emory International Law Review 21:335.

${ }^{24}$ Ibid., 336.
} 
at least one representative; in addition for each million of its population the ethnic group will receive an additional representative ${ }^{25}$.

While ethnofederalism in Ethiopia has not been wholeheartedly successful, evident through unfair elections and a centralized abusive federal government, there has been a vast improvement in ethnic representation and autonomy. The previously alienated peoples in periphery areas were given a level of autonomy ${ }^{26}$. Adoption of a capitalist economy created some economic success ${ }^{27}$. The political sphere was more accessible and the government received additional international aid because of its more western state ideals of federalism ${ }^{28}$.

Meles Zenawi, who was President of Ethiopia from 1991-1995, Prime Minister of Ethiopia from 1995 to the present and chairperson of both the TPLF and EPRDF, stated:

Sometimes, people in Africa feel that they can wish away ethnic difference. Experience in Rwanda has taught us this is not the case. Experience in Liberia has taught us that this is not the case. What we are trying to do in Ethiopia is to recognise that ethnic differences are part of life in Africa, and try to deal with them in a rational manner. Rather than hide the fact that we have ethnic difference, we are saying people should express it freely. That, I think, preempts the type of implosion we've had in Rwanda ${ }^{29}$

Zenawi has been successful in improving life under the ethnofederal regime. He has improved living condition for citizens, built new roads, clinics and primary schools ${ }^{30}$. In addition crime rates have been reduced and the economy has stabilized and is expected to grow by $10 \%$ in $2009^{31}$. However, despite the undeniable success

\footnotetext{
${ }^{25}$ Ibid., 336.

${ }^{26}$ The Economist. 2009. "The two sides of Meles Zenawi." Canadian Points of View Reference Centre 392:43.

${ }^{27}$ Clapham, Christopher. 2009. "Post-war Ethiopia: The Trajectories of Crisis." Review of African Political Economy 36:183.

${ }^{28}$ Ibid., 183.

${ }^{29}$ Tucker, Steven P. 1998. "Ethiopia in Transition.” Writenet, Unpublished Manuscript: 23.

${ }^{30}$ The Economist. 2009. "The two sides of Meles Zenawi." Canadian Points of View Reference Centre 392:43.

${ }^{31}$ Ibid., 44.
} 
the new regime has had in Ethiopia, the problem of ethnic conflict has still not been resolved.

In May 1998 a border dispute led to the Eritrean-Ethiopian War that lasted until June of $2000^{32}$. A binding decision was reached through arbitration; however, the EPRDF refused the decision and was engaged in a stalemate with Eritrean until 2006 when the Somalia border became a threat ${ }^{33}$. The 2005 general election left approximately 200 civilians dead in the capital city of Addis Abada, shot by police after protesting the results of the election following claims of ballot fraud by the government ${ }^{34}$. Over 10,000 arrests were made during the protests that followed the election; most individuals were detained without a trial or hearing and released weeks later while others still were transferred to a prison camp ${ }^{35}$. Norwegian election monitors declared the EPRDF's victory to be "neither fair, free, nor impartial"36. This demonstrates the persisting ethnic conflict between the minority governing class of the Tigrayan ethnic group and the other factions present within the country.

The federal government is alleged to have tortured and imprisoned opposition politics and critics of the new regime ${ }^{37} .76$ politicians, journalists and civil society activists were accused of treason and genocide and were placed in jail and brought to trial month later ${ }^{38}$. Within the Oromia state, authorities tortured and imprisoned believed supporters of the Oromo Liberation Front (OLF), an armed rebel group, and the Oromo National Congress (ONC), an opposition political party $^{39}$. Within the Gambella state, the Ethiopian military force is alleged to have killed, beaten, raped, tortured and arrested citizens without cause ${ }^{40}$.

\footnotetext{
${ }^{32}$ Human Rights Watch. 2006. "Ethiopia: Events of 2006." Human Rights Watch Online.

${ }^{33}$ Ibid.

${ }^{34}$ The Economist. 2009. "The two sides of Meles Zenawi." Canadian Points of View Reference Centre 392:44.

${ }^{35}$ Human Rights Watch. 2006. "Ethiopia: Events of 2006.” Human Rights Watch Online.

${ }^{36}$ Herther-Spiro, Nicole B. 2007. "Can Ethnic Federalism Prevent 'Recourse to Rebellion?': A Comparative Analysis of the Ethiopian and Iraqi Constitutional Structures." Emory International Law Review 21:337.

${ }^{37}$ Human Rights Watch. 2006. "Ethiopia: Events of 2006." Human Rights Watch Online.

${ }^{38}$ Ibid.

${ }^{39}$ Ibid.

${ }^{40}$ Ibid.
} 
Even in the most recent 2008 local and by-elections the EPRDF victory has been believed by many to be fraud because the only major opposition party, the Coalition for Unity and Democracy (CUD) was unable to campaign due to internal problems $^{41}$. In addition many opposition candidates and parties experienced powerful registration difficulties from the Federal government and were forced to withdraw from the race ${ }^{42}$.

Ethnic federalism is only successful when a balance in power-sharing is achieved among regions and the central government. If the states do not have enough autonomy, the ethnic conflicts will continue, but if they have too much then it will cripple the ability of the central government to rule effectively ${ }^{43}$. Within Ethiopia, the major cause of the lack of equilibrium of power is that the federal government has remained overly centralized $^{44}$. The EPRDF formed as a coalition between the TPLF and other popular political parties formed the majority of local and federal seats by eradicating opponents during the elections through force and intimidation ${ }^{45}$. The reason for the failure of this ethnofederalism system and the degradation into a Tigrayan ethnic dictatorship was a state failure by the federal government to decentralize power. Rather than facilitate dualidentity, ethnic federalism in this case is reinforcing divisions in society through regional resistance towards the controlling central government ${ }^{46}$.

The state's constitutional structure does not support a balance of power between the two levels of government within Ethiopia. The constitution was created by the EPRDF, formed by the Tigrayan faction representing an Ethiopian minority at approximately $10 \%$ of the population, while the Amara and Oromo factions represent

\footnotetext{
${ }^{41}$ International Crisis Group. 2009. "Ethiopia: Ethnic Federalism and Its Discontents.” International Crisis Group - Nairobi/Brussels.

42 Ibid.

${ }^{43}$ Herther-Spiro, Nicole B. 2007. “Can Ethnic Federalism Prevent 'Recourse to Rebellion?': A Comparative Analysis of the Ethiopian and Iraqi Constitutional Structures." Emory International Law Review 21:324.

${ }^{44}$ Ibid., 337.

${ }^{45}$ Ibid., 337.

${ }^{46}$ Hale, Henry E. 2004. "Institutional Sources of Ethnofederal State Survival and Collapse.” World Politics $56: 165$.
} 
$35 \%$ and $36 \%{ }^{47}$. A single minority creating the constitution is clearly in opposition to democratic federalist ideals.

This arrangement has created formal ethnic regions without significantly altering power relations in Ethiopia ${ }^{48}$. Much like history, the majority of Ethiopia is again being dominated by a minority. However, the system of ethnofederalism does not need to fail in Ethiopia; rather it can be successful if several key changes are made within the constitutional structure. It is the federal government's attempt to tightly control regional political processes that is undermining the ethnofederal system because the autonomy of the ethnic states are lost ${ }^{49}$.

There are several core reasons why the equilibrium of power between the central and state authority has failed. The issue of fiscal power is a key to understanding the ethnofederalism relationship between central and regional governance. Without fiscal independence, a state cannot be autonomous ${ }^{50}$. The central government controls the allocation of funds to states, in addition federally-collected funds are dispersed at the will of the central government, thus making the states extremely dependant on the good will of the central government ${ }^{51}$. This has caused an increase in ethnic competition over federal resources in terms of land, natural resources and government budgets ${ }^{52}$.

By not having state fiscal independence within Ethiopia, a state cannot act independently of the federal government in fear that this will affect the state's income received from the government. Thus states are obliged to represent the best interests of the EPRDF within their own state, which may not necessarily by the same as their own ethnic group's national interest. This partition of interests is a major contributing factor towards the ethnic faction conflicts as resent towards the Tigrayan people mounts as the federal government pushes their interests above the rest of the ethnic groups. To solve

\footnotetext{
${ }^{47}$ Ethiopia Central Statistical Agency. 1994. Population and Housing Census of 1994.

${ }^{48}$ Samatar, Abdi I. 2004. "Ethiopia Federalism: Autonomy versus Control in the Somalia Region." Third World Quarterly 25:1131.

${ }^{49}$ Ibid., 1133.

${ }^{50}$ Herther-Spiro, Nicole B

. 2007. 'Can Ethnic Federalism Prevent 'Recourse to Rebellion?': A Comparative Analysis of the

Ethiopian and Iraqi Constitutional Structures.” Emory International Law Review 21:358.

${ }^{51}$ Ibid., 359.

${ }^{52}$ International Crisis Group. 2009. "Ethiopia: Ethnic Federalism and Its Discontents.” International Crisis Group - Nairobi/Brussels.
} 
this problem, initiating a system where federal transfers to states are an automatic and equitable process, regardless of state compromise towards the will of the federal authority, would provide a more successful system for ending fiscal dependence. Without this dependence on the federal government, states would be able to achieve a greater level of autonomy which would allow them to pursue the national interests of their ethnic factions and not that of the faction in federal political power.

In terms of developing a theoretical framework for the implementation of ethnofederalism as a constitutional system within a state, it is clear that certain objectives must be achieved for this system to be effective. Specifically this paper argues for the necessity of the division of fiscal power between state and federal governments. This is due to the fact that a state is unable to be autonomous while still heavily dependent on the federal government for financial transfers. By instigating a system where a state is no longer totally dependent on imitating the views, in an effort to please, the federal government, a state will be able to properly represent the ethnic faction within. Thus this will achieve the objective of official recognition and representation that much of the ethnic conflict has been fought over.

Additionally the issue of equity between the ethnic factions is central to the success of an ethnofederal system. This is evident in Ethiopia where political parties align themselves with specific ethnic groups; the EPRDF has stated "ethnicity as the most important determinant for political and economic activities" ${ }^{, 53}$. Thus citizens must seek to protect themselves from the ethnic majority central government by declaring loyalty to an ethnic party which will protect their interests, further facilitating the ethnic divisions in society.

The theory behind ethnofederalism is that each ethnic group will have their interests represented. However, when a single ethnic group is in control of all the power, a successful ethnofederalism cannot function because the system is a facade. In actuality the ethnofederalism in Ethiopia has degraded into a dictatorship by the ethnic faction in power. This lack of equity between the ethnic groups, where the Tigrayan people have

\footnotetext{
${ }^{53}$ Herther-Spiro, Nicole B. 2007. “Can Ethnic Federalism Prevent 'Recourse to Rebellion?': A Comparative Analysis of the Ethiopian and Iraqi Constitutional Structures." Emory International Law Review 21:338.
} 
superiority in the state and other ethnic groups are severely underrepresented, is a catalyst to the ethnic conflict.

In developing a theoretical framework for the implementation of ethnofederalism, the importance of equity between the factions cannot be forgotten. While an ethnofederalism supports the idea of ethnic-based political representation, it cannot allow for Ethnonationalist domination by a single faction, because that would be a slipperyslope to a dictatorship. By allowing for the involvement of opposition parties and political representation by the non-ruling class there will be less ethnic conflict because the factions will accomplish their aim of representation within the government.

The EPRDF's failure to allow for political dissent is also a major problem towards the successful implementation of an ethnofederal system. Without the ability to form legitimate opposition parties and critique government actions a valid multi-party federalism cannot exist ${ }^{54}$. This has caused a further division between ethnic factions as the Ethiopian National Defense Force (ENDF), which has a monopoly in the use of power within the state, is mostly constructed of Tigrayan peoples and particularity comprised of the remnants of the Tigrayan Peoples Liberation Army ${ }^{55}$. Much of the violence reported within Ethiopia is inflicted by the ENDF on the other ethnic factions as a result of historical animosity. In addition the Prime Minister Zenawi claimed that "Eritrea is hell-bent on destabilizing Ethiopia" and that Eritrea is encouraging Oromo rebels and Somali separatists ${ }^{56}$.

With a Prime Minister engaging in the ethnic conflict by marginalizing ethnic groups, Ethiopia cannot successfully end these ethnic conflicts. A means of correcting this problem, towards ending faction conflict, would be tighter federal control over the actions of the ENDF which is involved in much of the conflict violent faction conflict. In addition, the federal government's strict attention to fair and free elections would end much of the resentment felt towards the EPRDF. In terms of developing a theoretical

\footnotetext{
${ }^{54}$ International Crisis Group. 2009. "Ethiopia: Ethnic Federalism and Its Discontents." International Crisis Group - Nairobi/Brussels.

${ }^{55}$ Kingma, Kees. 1997. "Demobilization of combatants after civil wars in Africa and their reintegration into civilian life". Policy Studies Journal 30:152.

56 The Economist. 2009. "The two sides of Meles Zenawi." Canadian Points of View Reference Centre $392: 44$
} 
framework for the implementation of ethnofederalism as a constitutional structure, the acceptance of political dissent and peaceful protesting is vitally important towards ensuring an end to faction violence.

Finally, there is a need for a fail-safe to be implemented which will act to prevent the federal domination of regional governance. For the national majority, Amara, and the EPRDF's Tigrayan peoples the ethnofederalism system provides a strong and unified state; however, for minorities within Ethiopia ethnofederalism remains artificial ${ }^{57}$. The EPRDF instigated a system of People's Democratic Organizations (PDO) which has proved entirely useless. The federal government formed these representations of local people interests through DERG prisoners' of war, low-level government employees and schoolteachers $^{58}$. Thus these individuals are viewed with suspicion by the community and are often loyal to the government because they are financially dependent on it for their job $^{59}$. PDO's imitate the interests of the federal government as a result, which furthers ethnic conflicts as local factions are still unable to gain legitimate representation within the government.

In this case, the training of local political elites could provide an answer to this problem of federal dominance over regional governments. By training these individuals with adept political skills, namely discussion, bargaining, compromise and recognition of alternative courses of authority, the state might be able to achieve a greater level of autonomy and ethnic representation which is the major cause of ethnic conflict ${ }^{60}$. For the development of a theoretical framework for the implementation of ethnofederalism it is imperative that fail-safe's are integrated into the system to prevent federal dominance of regional governance which could have the impact of overthrowing the entire system of ethnofederalism.

The importance of a successful balance of power, between federal and regional governments as necessary for a successful implementation of ethnofederalism, would be

\footnotetext{
${ }^{57}$ International Crisis Group. 2009. “Ethiopia: Ethnic Federalism and Its Discontents.” International Crisis Group - Nairobi/Brussels.

${ }^{58}$ Samatar, Abdi I. 2004. "Ethiopia Federalism: Autonomy versus Control in the Somalia Region." Third World Quarterly 25:1152.

${ }^{59}$ Ibid., 1152.

${ }^{60}$ Ibid., 1142.
} 
hugely beneficial for reducing ethnic conflict. The major obstacle to a successful ethnofederalism system, where ethnic conflict is largely eradicated, appears to relate to the EPRDF's devolutionary policies which seek to control all aspects of the political process $^{61}$. The fear of creating a balance of power between state and federal governments is that this equilibrium will lead to Ethiopia's disintegration, specifically because the 1994 Ethiopia constitution guarantees the right to self-determination up to secession ${ }^{62}$.

History can proved the legitimacy of this claim, as multi-national federations can be seen to be very unstable and commonly disintegrate over time ${ }^{63}$. Notable examples include the Soviet Union's disintegration in 1991 and Canada's near disintegration from the Quebecois in 1995. Thus the fear of the secession of multiple states within the ethnofederation of Ethiopia is a valid concern. However, this situation need not come to pass if the ethnic conflict within the country can be remedied. Already some advances have been made, recognisable the formal recognition of Somalis as an ethnic group within Ethiopia who are now the fourth largest population group and went unrecognized prior to the instigation of this constitutional system ${ }^{64}$.

Ethnofederalism is a viable solution for the ethnic conflict within Ethiopia; however, it has been the unsuccessful implementation of this constitutional system that as caused it failure to end faction violence. Specifically in terms of an unsuccessful division of fiscal power, lack of equity between ethnic groups, little federal toleration for political dissent and the federal domination of regional governance. The correction of these issues would further the success of the ethnofederal system and enforce an end to faction conflict. The silver lining of Ethiopia's unsuccessful attempt to instigate ethnofederalism, and the subsequent violence that has ensued, is that it has allowed for an unsuccessful ethnofederalism system to be studied. Specifically the vital importance of a balance of power between the federal and state autonomy in order to end ethnic conflict would be a major issue to be addressed in correcting unsuccessful an ethnofederalism.

\footnotetext{
${ }^{61}$ Ibid., 1142

${ }^{62}$ Ibid., 1132.

${ }^{63}$ Herther-Spiro, Nicole B. 2007. “Can Ethnic Federalism Prevent 'Recourse to Rebellion?': A Comparative Analysis of the Ethiopian and Iraqi Constitutional Structures." Emory International Law Review 21:338.

${ }^{64}$ Ethiopia Central Statistical Agency. 1994. Population and Housing Census of 1994.
} 


\section{Bibliography}

Adegehe, Asnake K. 2009. Federalism and ethnic conflict in Ethiopia: a comparative study of the Somali and Benishangul-Gumuz regions. Leiden: Leiden University Press.

Clapham, Christopher. 2009. "Post-war Ethiopia: The Trajectories of Crisis." Review of African Political Economy 36:181-92.

Ethiopia Central Statistical Agency. 1994. Population and Housing Census of 1994. The Federal Democratic Republic of Ethiopia.

$<$ http://www.csa.gov.et/surveys/Population $\% 20$ and $\% 20$ Housing $\% 20$ Census $\% 201$ 994/survey0/index.html>.

Hale, Henry E. 2004. "Institutional Sources of Ethnofederal State Survival and Collapse." World Politics 56:165-93.

Herther-Spiro, Nicole B. 2007. "Can Ethnic Federalism Prevent 'Recourse to Rebellion?': A Comparative Analysis of the Ethiopian and Iraqi Constitutional Structures." Emory International Law Review 21:321-71.

Human Rights Watch. 2006. "Ethiopia: Events of 2006." Human Rights Watch Online. < http://www.hrw.org/legacy/englishwr2k7/docs/2007/01/11/ethiop14704.htm>.

International Crisis Group. 2009. "Ethiopia: Ethnic Federalism and Its Discontents." International Crisis Group - Nairobi/Brussels.

$<$ http://www.crisisgroup.org/home/index.cfm?id=6300 $>$.

Kingma, Kees. 1997. "Demobilization of combatants after civil wars in Africa and their reintegration into civilian life". Policy Studies Journal 30:151-65.

Samatar, Abdi I. 2004. "Ethiopia Federalism: Autonomy versus Control in the Somalia Region." Third World Quarterly 25:1131-54.

Smith, Lahra. 2007. "Voting for an ethnic identity: procedural and institutional responses to ethnic conflict in Ethiopia." Journal of modern African studies 45:565-94.

The Economist. 2009. "The two sides of Meles Zenawi." Canadian Points of View Reference Centre 392:43-4.

$<$ http://web.ebscohost.com/pov/detail?vid=2\&hid=9\&sid=412f6bf4-1eb8-4f6c$902 \mathrm{e}$ 60890828312c\%40sessionmgr10\&bdata $=$ JnNpdGU9cG92LWNhbg\%3d\%3d\#db= p3h\&AN=43978160>.

Tucker, Steven P. 1998. "Ethiopia in Transition." Writenet, Brighton, Unpublished Manuscript: 23. 